\title{
Aplikasi Kalsium dan NAA untuk Mengendalikan Getah Kuning Buah Manggis (Garcinia mangostana L.)
}

\author{
Application of Calcium and NAA to Control Yellow Sap Contamination \\ of Mangosteen Fruit ( $\underline{\text { Garcinia }}$ mangostana L.)
}

Yulinda Tanari' ${ }^{1}$ Darda Efendi ${ }^{2 *}$, Roedhy Poerwanto $^{2}$, Didy Sopandie ${ }^{2}$, dan Ketty Suketi $^{2}$

Diterima 01 November 2017/Disetujui 08 Februari 2018

\begin{abstract}
The yellow sap is produced naturally in mangosteen organ except in the root. The yellow sap contaminated the aryl and rind if the epithelial cell walls rupture due to deficiency of calcium $(\mathrm{Ca})$. Calcium is one of structural component of cell walls, whereas naphthaleneacetic acid (NAA) has its role in improving cell division and cell elongation. Interaction of Ca and NAA can improve sink strength and capacity because the newly formed cells need Ca to construct wall structure. This experiment aimed at finding out the effect of $\mathrm{Ca}$ and NAA applications in reducing the contamination of yellow sap in mangosteen. The experiment was conducted by using factorial random block design consisting of 2 factors and 3 replications. The first factor was Ca dosage $(0$ and $4.8 \mathrm{~kg} /$ tree), and the second factor was NAA concentration $(0,200,400$ and $600 \mathrm{ppm})$. The results showed that application of 4.8 Ca/tree and $200 \mathrm{ppm} N A A$ as much as $5 \mathrm{ml} /$ fruit effectively improve the content of Ca pectate in pericarp, reduced the percentage of yellow sap contamination on the fruit segment, aryl and rind to 0\% and $12.3 \%$ respectively compared to control $(17.8 \%$ on fruit segment, $36.8 \%$ on aryl and $56.1 \%$ on rind).
\end{abstract}

Key words: aryl, Ca pectate, cell wall, middle lamela.

\begin{abstract}
ABSTRAK
Getah kuning adalah getah yang dihasilkan secara alami pada setiap organ manggis, kecuali pada akar. Getah kuning akan keluar dan mencemari aril serta kulit jika dinding sel epitel pecah karena kekurangan kalsium (Ca). Kalsium adalah komponen dinding sel, berperan dalam struktur dan permeabilitas membran sedangkan asam naftalenasetat (NAA) berperan penting dalam meningkatkan pembelahan dan pembesaran sel. Interaksi keduanya dapat meningkatkan kapasitas sink buah karena sel yang baru terbentuk membutuhkan Ca dalam menyusun struktur dinding sel. Percobaan bertujuan untuk mengetahui pengaruh aplikasi Ca dan NAA dalam menurunkan cemaran getah kuning manggis. Percobaan menggunakan rancangan acak kelompok faktorial 2 faktor dengan 3 ulangan. Faktor ke-1 yaitu dosis $\mathrm{Ca}(0$ dan $4.8 \mathrm{~kg} \mathrm{Ca} /$ pohon) dan faktor ke-2 yaitu konsentrasi NAA $(0,200,400$ dan $600 \mathrm{ppm})$ dengan volume semprot $5 \mathrm{ml}$ perbuah. Hasil percobaan menunjukkan bahwa aplikasi $4.8 \mathrm{~kg} \mathrm{Ca} /$ pohon dengan NAA $200 \mathrm{ppm}$ sebanyak $5 \mathrm{ml} /$ buah efektif meningkatkan kandungan $\mathrm{Ca}$ pektat perikarp dan menurunkan persentase buah tercemar getah kuning menjadi $0 \%$ pada juring dan aril serta $12.3 \%$ pada kulit dibandingkan dengan perlakuan kontrol (17.8\% pada juring, $36.8 \%$ pada aril dan $56.1 \%$ pada kulit buah).
\end{abstract}

Kata kunci: aril, Ca pektat, dinding sel, lamela tengah

\footnotetext{
${ }^{1}$ Mahasiswa Pascasarjana, Departemen Agronomi dan Hortikultura, Fakultas Pertanian, Institut Pertanian Bogor ${ }^{2}$ Departemen Agronomi dan Hortikultura, Fakultas Pertanian, Institut Pertanian Bogor

J1. Meranti Kampus Darmaga, Bogor 16680 Indonesia.

Email: dardaefendi@yahoo.com (*Penulis korespondensi)
} 


\section{PENDAHULUAN}

Manggis (Garcinia mangostana L.) merupakan komoditas hortikultura yang dijuluki queen of tropical fruit. Manggis menjadi buah primadona ekspor Indonesia yang menjadi andalan untuk menambah devisa negara, namun persentase buah manggis yang dapat diekspor masih rendah dibandingkan dengan produksinya. Buah manggis yang dapat diekspor hanya $14.8 \%$ dari total produksi nasional (BPS, 2015; Kementan, 2015). Salah satu penyebab rendahnya ekspor ialah getah kuning yang mencemari daging buah (aril) dan kulit buah. Getah kuning menyebabkan aril menjadi pahit dan penampilan buah tidak menarik (Osman dan Milan, 2006).

Getah kuning ialah getah yang dihasilkan secara alami pada setiap organ manggis, kecuali pada akar (Dorly et al., 2008). Getah kuning terdapat dalam saluran getah yang terdiri atas lumen besar yang dikelilingi oleh sel-sel epitel yang khas (Dorly et al., 2008). Getah kuning akan menjadi rusak bila sel epitel yang merupakan penyusun saluran getah lemah. Rusaknya sel epitel disebabkan perubahan air tanah yang ekstrim selama proses perkembangan buah (Syah et al., 2009; Pechkeo et al., 2007), serta perbedaan laju pertumbuhan antara biji dan aril dengan bagian perikarp buah selama fase pembesaran buah (Poerwanto et al., 2010).

Pecahnya saluran getah kuning berkaitan dengan unsur kalsium (Ca). Kandungan $\mathrm{Ca}$ pada perikarp buah manggis yang tercemar getah kuning lebih rendah dibandingkan dengan buah normal (Poovaradom dan Sumitra, 2009; Purnama et al., 2013; Kurniadinata et al., 2016a; Kurniawan et al., 2016). Kalsium berperan dalam menentukan kekakuan (rigidity) dinding sel, sesuai peran ion $\mathrm{Ca}$ sebagai penghubung antara rantai pektin pada dinding sel (Taiz dan Zeiger, 2010). Menurut Seligmann et al. (2009) Ca pada tanaman memiliki peran penting terkait dengan kekuatan mekanik jaringan dan terlibat dalam menentukan kualitas buah.

Kalsium merupakan komponen dinding sel, berperan dalam struktur dan permeabilitas membran sedangkan NAA berperan penting dalam meningkatkan pembelahan dan pembesaran sel. Upaya untuk meningkatkan serapan $\mathrm{Ca}$ ke buah pada percobaan ini menggunakan aplikasi Ca dan NAA. Dosis Ca berdasarkan kandungan hara awal (Tabel 1) dan rekomendasi dari hasil percobaan Tanari dan Tinggogoy (2014), bahwa dosis 3 ton/ha $\mathrm{Ca}$ atau setara dengan $4.8 \mathrm{~kg} \mathrm{Ca} /$ pohon efektif menurunkan persentase cemaran getah kuning sebesar 52.6\% di Desa Kamba Kabupaten Poso. Konsentrasi NAA yang terbaik untuk meningkatkan kualitas buah jeruk (meningkatkan bobot dan mengurangi absisi buah) adalah konsentrasi 300 dan $400 \mathrm{ppm}$ (Greenberg et al., 2006; Amiri et al., 2013).

Abbasi et al. (2013) menyatakan bahwa NAA dapat meningkatkan penyerapan Ca ke buah tomat dan menurut Karin (2013) NAA merupakan senyawa yang menginduksi pembelahan dan pembesaran sel, karena itu diduga pembelahan sel pada buah karena aplikasi NAA akan menjadikan buah sebagai sink yang kuat karena sel yang baru terbentuk membutuhkan $\mathrm{Ca}$ untuk menempati dan menyusun struktur dinding sel.

Percobaan ini bertujuan mengetahui pengaruh $\mathrm{Ca}$ dan NAA untuk menurunkan cemaran getah kuning manggis dengan aplikasi Ca melalui tanah dan penyemprotan NAA ke buah manggis.

\section{BAHAN DAN METODE}

Percobaan dilaksanakan di Desa Kamba, Kecamatan Pamona Timur, Kabupaten Poso, Sulawesi Tengah pada bulan Oktober 2015 hingga April 2016. Pengamatan terhadap cemaran getah kuning dilakukan di Laboratorium Ilmu Alamiah Dasar Universitas Sintuwu Maroso, Poso. Analisis kimia tanah dan jaringan tanaman dilakukan di Laboratorium Kimia dan Kesuburan Tanah IPB.

Bahan-bahan yang digunakan dalam percobaan ini adalah dolomit, NAA, $\mathrm{NaCl}$, aquades, buah manggis yang berasal dari 24 pohon berumur 40 tahun yang berada pada fase pembungaan dengan jarak tanam $4 \mathrm{~m} \mathrm{x} 4$ m sampai $6 \mathrm{~m} \times 6 \mathrm{~m}$ dengan kanopi yang relatif seragam.

Percobaan ini menggunakan rancangan acak kelompok faktorial yang terdiri atas 2 faktor yaitu dosis $\mathrm{Ca}$ dan konsentrasi NAA. 
Dosis $\mathrm{Ca}$ terdiri atas 2 taraf yaitu $0 \mathrm{~kg} /$ pohon dan $4.8 \mathrm{~kg} /$ pohon. Konsentrasi NAA terdiri atas 4 taraf yaitu $0 \mathrm{ppm}, 200 \mathrm{ppm}, 400 \mathrm{ppm}$, dan 600 ppm. Terdapat 8 kombinasi perlakuan yang diulang 3 kali sehingga terdapat 24 satuan percobaan. Setiap satuan percobaan menggunakan 1 pohon dengan jumlah sampel sebanyak 19 buah/pohon, sehingga total buah manggis yang digunakan adalah 456 buah. Pemberian Ca dilakukan pada saat antesis dengan cara ditabur dalam larikan di bawah tajuk tanaman $5 \mathrm{~cm}$ dari permukaan tanah, sedangkan NAA diberikan 1 minggu setelah antesis (MSA) dengan cara menyemprot buah sesuai dengan perlakuan sampai semua bagian buah basah yaitu $5 \mathrm{ml} / \mathrm{buah}$. Panen dilaksanakan secara serentak pada saat 16 MSA.

Komponen yang diamati adalah skor (Tabel 2 dan 3) dan persentase buah yang aril, kulit dan juringnya tercemar getah kuning, kandungan Ca pektat pada perikarp buah serta bobot buah dan bagian-bagian buah (kulit, sepal, tangkai, aril dan biji).
Pengamatan terhadap persentase buah yang aril dan kulitnya tercemar getah kuning dilakukan untuk mengetahui intensitas cemaran pada buah yang diamati. Buah dianggap tercemar meskipun getah kuning yang mengotori aril atau kulit hanya sedikit, dihitung menggunakan rumus jumlah buah yang kulit atau arilnya tercemar getah kuning dibagi total buah yang diamati. Pengamatan terhadap persentase jumlah buah yang juringnya tercemar getah kuning dilakukan untuk mengetahui banyaknya juring yang tercemar getah kuning, dihitung berdasarkan jumlah juring tercemar terhadap jumlah juring/buah (Kurniadinata et al. 2016b).

Skor cemaran getah kuning menunjukkan tingkat keparahan getah kuning yang mencemari buah, diperingkatkan dari 1 (baik sekali) sampai 5 (buruk sekali). Pengamatan terhadap skor buah yang aril dan kulitnya tercemar getah kuning mengacu pada Kurniadinata et al. (2016b) seperti pada Tabel 2 dan 3.

Tabel 1. Kandungan hara dan tekstur tanah pada tanah areal kebun manggis Desa Kamba, Kabupaten Poso

\begin{tabular}{lc}
\hline Sifat Tanah & Hasil Analisis* \\
\hline $\mathrm{pH} \mathrm{H} 0$ & 4.40 \\
$\mathrm{~N}$ total\% & 0.10 \\
$\mathrm{P}$ bray $(\mathrm{ppm})$ & 0.35 \\
$\mathrm{Ca}\left(\mathrm{cmol}^{(+)} / \mathrm{kg}\right)$ & 0.57 \\
$\mathrm{~K}\left(\mathrm{cmol}^{(+)} / \mathrm{kg}\right)$ & 0.12 \\
$\left.\mathrm{KTK}_{(\mathrm{cmol}}{ }^{+} / \mathrm{kg}\right)$ & 8.09 \\
$\mathrm{Al}\left(\mathrm{cmol}^{(+)} / \mathrm{kg}\right)$ & 2.39 \\
\hline
\end{tabular}

Keterangan: *)Analisis dilakukan pada Laboratorium Departemen Ilmu Tanah dan Sumber Daya Lahan, IPB)

Tabel 2. Skor cemaran getah kuning pada aril

\begin{tabular}{|c|c|}
\hline Skor & Keterangan \\
\hline 1 & $\begin{array}{l}\text { Baik sekali, aril putih bersih, tidak terdapat getah kuning baik di antara aril dengan } \\
\text { kulit maupun di pembuluh buah }\end{array}$ \\
\hline 2 & $\begin{array}{l}\text { Baik, aril putih, terdapat } 1-2 \text { noda (bercak kecil) getah kuning pada satu ujung aril, } \\
\text { namun tidak memberikan rasa pahit }\end{array}$ \\
\hline 3 & $\begin{array}{l}\text { Cukup baik, terdapat beberapa noda (bercak) getah kuning di salah satu ujung juring } \\
\text { atau di antara juring dan mengotori aril }\end{array}$ \\
\hline 4 & $\begin{array}{l}\text { Buruk, terdapat noda/gumpalan getah kuning baik di ujung juring, di antara juring atau } \\
\text { di pembuluh buah yang menyebabkan rasa buah menjadi pahit }\end{array}$ \\
\hline 5 & $\begin{array}{l}\text { Buruk sekali, terdapat noda/gumpalan besar baik di juring, di antara juring atau di } \\
\text { pembuluh buah yang menyebabkan rasa buah menjadi pahit, warna aril menjadi } \\
\text { bening }\end{array}$ \\
\hline
\end{tabular}


Tabel 3. Skor cemaran getah kuning pada kulit

\begin{tabular}{ll}
\hline Skor & \multicolumn{1}{c}{ Keterangan } \\
\hline 1 & $\begin{array}{l}\text { Baik sekali, kulit mulus tanpa terlihat getah kuning } \\
\text { Baik, kulit mulus dengan 1-5 gumpalan kecil getah kuning yang mengering tanpa } \\
\text { memengaruhi warna buah }\end{array}$ \\
3 & $\begin{array}{l}\text { Cukup baik, kulit mulus dengan 6-10 tetes kecil getah kuning yang mengering dan } \\
\text { tidak memengaruhi warna buah }\end{array}$ \\
4 & $\begin{array}{l}\text { Buruk, kulit kotor karena gumpalan sedang/besar getah kuning, terdapat 1-2 bekas } \\
\text { aliran yang menguning }\end{array}$ \\
5 & $\begin{array}{l}\text { Buruk sekali, kulit kotor karena terdapat lebih dari satu gumpalan besar getah kuning, } \\
\text { terdapat banyak jalur-jalur berwarna kuning di permukaan buah, dan warna buah } \\
\text { menjadi kusam }\end{array}$ \\
\hline
\end{tabular}

Keterangan: Nilai 1 (terbaik/tanpa cemaran) hingga nilai 5 (terburuk/memiliki skor cemaran tertinggi).

Pengamatan terhadap bobot buah dan bagian-bagian buah diukur dengan menggunakan timbangan digital dengan cara menimbang buah dan bagian-bagiannya pada saat setelah panen. Analisis Ca pektat pada mengacu pada metode analisis Ca pektat oleh Setyaningrum et al. (2011) dengan prosedur sampel buah yang telah dikeringkan dan dihancurkan ditambahkan air bebas ion, dikocok selama 2 jam kemudian disentrifugasi selama 15 menit dengan kecepatan $3000 \mathrm{rpm}$. Supernatan disaring kemudian pellet ditambahkan $1 \mathrm{~mol} \mathrm{~L}^{-1}$ larutan $\mathrm{NaCl}$, dikocok selama 2 jam dan disentrifugasi selama 15 menit. Hasil ekstraksi dianalisis dengan Atomic Absorbtion Spectrophotometer (AAS) untuk mendapatkan data Ca pektat.

Data persentase buah yang juringnya tercemar getah kuning, skor dan persentase buah yang aril dan kulitnya tercemar getah kuning dianalisis dengan uji Kruskal-Wallis dan uji lanjut Dunn. Data bobot buah dan bagian-bagiannya dianalisis menggunakan sidik ragam, dan uji lanjut Duncan Multiple Range Test (DMRT) pada taraf 5\% dan $1 \%$.

\section{HASIL DAN PEMBAHASAN}

Hasil analisis tanah awal (Tabel 1) pada lahan percobaan di Desa Kamba, kandungan $\mathrm{Ca}$ tanah termasuk dalam kategori sangat rendah $\left(0.57 \mathrm{cmol}^{+} \mathrm{kg}^{-1}\right)$. Berdasarkan kriteria penilaian sifat-sifat kimia tanah oleh Pusat Penelitian Tanah (1982), kandungan $\mathrm{Ca}<2$ $\mathrm{cmol}^{+} \mathrm{kg}^{-1}$ dikategorikan sangat rendah. Rendahnya kandungan $\mathrm{Ca}$ tanah pada lokasi percobaan berpengaruh terhadap rendahnya pasokan $\mathrm{Ca}$ ke buah manggis, menyebabkan terjadinya kelainan fisiologi berupa cemaran getah kuning. Menurut Martias et al. (2012) cemaran getah kuning secara langsung dikendalikan oleh ketersediaan $\mathrm{Ca}$ dalam tanah. Menurut Combrink (2013) dan Jemric et al. (2016) defisiensi $\mathrm{Ca}$ menyebabkan timbulnya kelainan fisiologi pada apel dan beberapa tanaman buah. Hocking et al. (2016) menyatakan bahwa bila suplai dan transport $\mathrm{Ca}$ rendah, akan terjadi defisiensi $\mathrm{Ca}$ yang menyebabkan kerusakan membran dan dinding sel pada buah tomat.

\section{Persentase Cemaran Getah Kuning}

Hasil percobaan menunjukkan bahwa kombinasi Ca dan NAA terbukti menurunkan cemaran getah kuning pada aril dan kulit buah manggis. Kandungan Ca pektat perikarp pada kombinasi $4.8 \mathrm{~kg} \mathrm{Ca} /$ pohon dengan $200 \mathrm{ppm}$ NAA sama baiknya dengan $4.8 \mathrm{~kg} \mathrm{Ca} /$ pohon dengan 0 ppm NAA. Persentase buah yang tercemar getah kuning pada kulit, aril dan juring serta kandungan $\mathrm{Ca}$ pektat perikarp disajikan pada Tabel 4.

Data pada Tabel 4 menunjukkan bahwa walaupun memiliki kandungan $\mathrm{Ca}$ pektat perikarp yang sama, namun kombinasi $4.8 \mathrm{~kg}$ $\mathrm{Ca} /$ pohon dengan 0 ppm NAA menyebabkan penurunan cemaran getah kuning sebesar $83.1 \%$ pada juring, $52.4 \%$ pada aril dan $49.9 \%$ pada kulit sedangkan kombinasi $4.8 \mathrm{~kg}$ $\mathrm{Ca}$ /pohon dengan 200 ppm NAA menurunkan cemaran getah kuning sebesar $100 \%$ pada juring dan aril buah, $78 \%$ pada kulit dibandingkan dengan kontrol. Dengan demikian perlakuan kombinasi $4.8 \mathrm{~kg}$ $\mathrm{Ca} /$ pohon dan 200 ppm NAA lebih efektif dalam menurunkan persentase buah yang tercemar getah kuning pada juring, aril dan kulit. 
Tabel 4. Persentase buah yang juring, aril dan kulitnya tercemar getah kuning serta kandungan Ca pektat perikarp pada aplikasi Ca dan NAA 16 MSA

\begin{tabular}{|c|c|c|c|c|c|}
\hline \multicolumn{2}{|c|}{ Perlakuan } & \multicolumn{3}{|c|}{ Buah yang Tercemar Getah Kuning (\%) } & \multirow{2}{*}{$\begin{array}{c}\text { Ca Pektat } \\
\text { Perikarp (ppm) }\end{array}$} \\
\hline $\mathrm{Ca}(\mathrm{kg} / \mathrm{pohon})$ & NAA(ppm) & Juring & Aril & Kulit & \\
\hline \multirow[t]{4}{*}{0} & 0 & $17.8 \mathrm{a}$ & $36.8 \mathrm{a}$ & $56.1 \mathrm{~b}$ & $141.67 \mathrm{c}$ \\
\hline & 200 & $4.3 \mathrm{bc}$ & $12.3 \mathrm{~b}$ & $52.6 \mathrm{~b}$ & $123.87 \mathrm{c}$ \\
\hline & 400 & $4.9 \mathrm{ab}$ & $29.8 \mathrm{a}$ & $66.7 \mathrm{a}$ & $131.73 \mathrm{c}$ \\
\hline & 600 & $5.8 \mathrm{c}$ & $14.0 \mathrm{~b}$ & $50.6 \mathrm{~b}$ & $151.53 \mathrm{~b}$ \\
\hline \multirow[t]{4}{*}{4.8} & 0 & $3.0 \mathrm{bc}$ & $17.5 \mathrm{~b}$ & $28.1 \mathrm{c}$ & $196.00 \mathrm{ab}$ \\
\hline & 200 & $0.0 \mathrm{~d}$ & $0.0 \mathrm{c}$ & $12.3 \mathrm{~d}$ & $216.40 \mathrm{a}$ \\
\hline & 400 & $2.3 \mathrm{~cd}$ & $8.8 \mathrm{bc}$ & $59.7 \mathrm{~b}$ & $156.40 \mathrm{bc}$ \\
\hline & 600 & $3.7 \mathrm{bc}$ & $17.5 \mathrm{~b}$ & $36.8 \mathrm{c}$ & $141.07 \mathrm{c}$ \\
\hline
\end{tabular}

Keterangan : Data diuji berdasarkan uji peringkat Kruskal-Wallis (\% cemaran) dan analisis sidik ragam (kandungan Ca pektat). Angka-angka yang diikuti oleh huruf yang berbeda pada kolom yang sama berbeda nyata berdasarkan uji Dunn $1 \%$ dan DMRT $5 \%$.

Aplikasi NAA diduga menyebabkan peningkatan pembelahan sel buah sehingga terbentuk sel-sel baru pada buah. Buah menjadi sink yang kuat karena sel-sel yang baru terbentuk membutuhkan $\mathrm{Ca}$ untuk menyusun struktur dinding selnya. Keberadaan $\mathrm{Ca}$ yang tinggi pada dinding sel epitel menyebabkan sel penyusun saluran sekretori menjadi kuat sehingga getah tidak keluar mencemari aril dan kulit buah manggis. Menurut Taiz dan Zaiger (2010) Ca merupakan konstituen lamela tengah pada dinding sel dan menurut Marschner (2012) proporsi $\mathrm{Ca}$ yang tinggi ditemukan pada dinding sel (apoplas).

\section{Skor Cemaran Getah Kuning}

Aplikasi $4.8 \mathrm{~kg} \mathrm{Ca} /$ pohon dengan 200 ppm NAA menghasilkan skor buah yang kulitnya tercemar getah kuning lebih rendah dibandingkan dengan semua kombinasi perlakuan lainnya, sedangkan pada peubah skor buah yang arilnya tercemar getah kuning, aplikasi $4.8 \mathrm{~kg} \mathrm{Ca} /$ pohon dengan 200 maupun 400 ppm NAA sama baiknya dalam menurunkan cemaran getah kuning (Tabel 5).

Skor getah kuning menunjukkan tingkat keparahan getah yang mencemari aril ataupun kulit buah, semakin besar skor berarti semakin parah kejadian getah kuning. Data pada Tabel 5 menunjukkan bahwa terjadi penurunan tingkat keparahan getah kuning dengan aplikasi $4.8 \mathrm{~kg} \mathrm{Ca} /$ pohon dengan $200 \mathrm{ppm}$, baik pada aril maupun pada kulit buah. Konsentrasi Ca yang rendah pada sel epitel penyusun saluran getah akan menyebabkan tingkat keparahan cemaran getah menjadi lebih besar. Menurut hasil penelitian de Freitas et al. $(2010,2011)$ kondisi $\mathrm{Ca}^{2+}$ apoplastik yang rendah sangat berhubungan dengan kebocoran membran, plasmolisis bahkan kematian sel pada buah apel dan tomat.

Peningkatan kandungan Ca pektat pada perikarp buah menyebabkan penurunan persentase dan skor buah yang tercemar getah kuning (Tabel 4 dan 5). Hal ini membuktikan bahwa terbentuknya kompleks Ca pektat dapat memperkokoh sel epitel sehingga keberadaannya dapat mencegah getah keluar dari lumen dan mencemari aril dan kulit buah. Menurut Saure (2005) Ca dapat menstabilkan membran sel untuk menjaga kerusakan fisiologi karena kekurangan $\mathrm{Ca}$ pada buah apel. Hasil penelitian Abbasi et al. (2013) menunjukkan bahwa kombinasi NAA dan $\mathrm{Ca}$ menghasilkan kandungan $\mathrm{Ca}$ yang lebih tinggi dibandingkan dengan buah yang diberi perlakuan hanya dengan Ca pada buah tomat.

Persentase dan skor cemaran getah kuning pada kulit meningkat pada konsentrasi yang lebih besar dari 200 ppm, sedangkan pada aril dan juring meningkat pada konsentrasi yang lebih besar dari $400 \mathrm{ppm}$ (Tabel 4 dan 5). Diduga konsentrasi NAA yang tinggi dapat menghambat pertumbuhan sel tanaman (menghambat pertumbuhan sel apoplas baru). Dengan demikian sel-sel baru tidak tersedia untuk $\mathrm{Ca}$. Vince dan Zoltan (2011) menyatakan bahwa konsentrasi auksin yang optimal untuk pertumbuhan (pemanjangan) batang kacang polong dan koleoptil oat adalah 0.0355 sampai $0.355 \mathrm{ppm}$. Penghambatan terjadi ketika konsentrasi auksin melebihi tingkat optimal tersebut. 
J. Hort. Indonesia 9(1): 10-18. April 2018.

Tabel 5. Skor buah yang aril dan kulitnya tercemar getah kuning pada aplikasi Ca dan NAA 16 MSA

\begin{tabular}{lcll}
\hline \multicolumn{2}{c}{ Perlakuan } & \multicolumn{2}{c}{ Skor Cemaran Getah Kuning* } \\
\hline Ca (kg/pohon) & NAA $(\mathrm{ppm})$ & Aril & Kulit \\
\hline 0 & 0 & $1.9 \mathrm{a}$ & $2.2 \mathrm{ab}$ \\
& 200 & $1.3 \mathrm{bc}$ & $1.5 \mathrm{c}$ \\
& 400 & $1.3 \mathrm{~b}$ & $2.4 \mathrm{a}$ \\
4.8 & $1.3 \mathrm{c}$ & $2.0 \mathrm{~b}$ \\
& 000 & $1.2 \mathrm{c}$ & $1.3 \mathrm{~d}$ \\
& 200 & $1.0 \mathrm{~d}$ & $1.1 \mathrm{e}$ \\
& 400 & $1.1 \mathrm{~cd}$ & $1.5 \mathrm{c}$ \\
& 600 & $1.3 \mathrm{bc}$ & $1.4 \mathrm{~cd}$ \\
\hline
\end{tabular}

Keterangan : Data skoring diuji berdasarkan uji peringkat Kruskal-Wallis. Angka-angka yang diikuti oleh huruf yang berbeda pada kolom yang sama berbeda nyata berdasarkan uji Dunn 1\%. *Skor 1: Baik sekali; skor 2: Baik; skor 3: Cukup baik; skor 4: Buruk; skor 5: Buruk sekali.

\section{Fisik Buah Manggis}

Perlakuan dosis Ca, konsentrasi NAA serta kombinasi keduanya memiliki pengaruh yang sama terhadap bobot buah dan bagianbagiannya (Tabel 6). Menurut Danner et al., (2015) aplikasi Ca menyebabkan peningkatan kekerasan buah apel tetapi tidak mempengaruhi bobot buah. Demikian pula pada manggis, aplikasi $\mathrm{Ca}$ menurunkan cemaran getah kuning tetapi tidak mempengaruhi bobot buah manggis Kurniawan et al. (2016).

Aplikasi 300 dan 400 ppm NAA meningkatkan ukuran buah jeruk Nova mandarin dan jeruk Satsuma mandarin (Greenberg et al., 2006; Amiri et al., 2013), serta pada konsentrasi 1000 ppm meningkatkan panjang dan berat kering akar pada tanaman anggur Virginia (Taleb et al.,
2012) berbeda dengan hasil percobaan ini yang menghasilkan data rata-rata bobot buah manggis yang cenderung mengalami penurunan karena peningkatan konsentrasi NAA. Konsentrasi NAA yang tinggi menghambat pertumbuhan sel sehingga menyebabkan penurunan bobot buah manggis dan juga meningkatkan cemaran getah kuning manggis. Kramer dan Ackelsberg (2015) menyatakan bahwa auksin berperan dalam semua aspek pertumbuhan dan perkembangan tanaman dan menurut Thimann (2008) selain berperan untuk meningkatkan pertumbuhan, auksin juga bersifat menghambat pertumbuhan. Terjadi kerusakan berupa busuk stek herba pada aplikasi auksin sebesar 25 ppm, sedangkan pada stek tanaman berkayu kerusakan serupa dapat terjadi pada konsentrasi auksin sebesar 100-200 ppm.

Tabel 6. Bobot buah dan bagian-bagiannya pada perlakuan aplikasi Ca dan NAA

\begin{tabular}{lcccccc}
\hline \multirow{2}{*}{ Perlakuan } & \multicolumn{7}{c}{ Bobot $(\mathrm{g})$} \\
\cline { 2 - 7 } & Buah & Kulit & Sepal & Tangkai & Aril & Biji \\
\hline Ca (kg/pohon) & & & & & & \\
0 & 74.16 & 47.27 & 1.57 & 1.13 & 22.74 & 0.96 \\
4.8 & 76.31 & 48.91 & 1.66 & 1.10 & 22.78 & 1.10 \\
NAA (ppm) & & & & & & \\
$\quad 0$ & 87.28 & 56.14 & 1.73 & 1.29 & 26.47 & 1.10 \\
200 & 76.03 & 48.75 & 1.65 & 1.13 & 22.70 & 1.18 \\
400 & 72.15 & 46.45 & 1.58 & 1.10 & 21.55 & 0.88 \\
600 & 65.49 & 41.02 & 1.48 & 0.94 & 20.31 & 0.80 \\
\hline Interaksi & tn & tn & tn & tn & tn & tn \\
\hline
\end{tabular}

Keterangan: $\mathrm{tn}=$ tidak nyata. 


\section{KESIMPULAN}

Aplikasi $4.8 \mathrm{~kg} \mathrm{Ca} /$ pohon dengan 200 ppm NAA (5 ml/buah) dengan cara disemprotkan pada buah efektif meningkatkan kandungan $\mathrm{Ca}$ pektat perikarp dan menurunkan persentase buah tercemar getah kuning menjadi $0 \%$ pada juring dan aril serta $12.3 \%$ pada kulit dibandingkan dengan perlakuan kontrol (17.8\% pada juring, 36.8\% pada aril dan $56.1 \%$ pada kulit buah).

\section{DAFTAR PUSTAKA}

Abbasi, N.A., L. Zafar, H.A. Khan, A.A. Qureshi. 2013. Effects of naphthalene acetic acid and calcium chloride application on nutrient uptake, growth, yield and post harvest performance of tomato fruit. J. Bot. 45(3): 1581-1587.

Amiri, N.A., A.A. Kangarshahi, K. Arzani. 2013. Reducing of citrus losses by spraying of synthetic auxins. Intl J Agri Crop Sci. 4(22): 1720-1724.

[BPS] Badan Pusat Statistik. 2015. Produksi Buah-buahan di Indonesia 2015. https://www.bps.go.id/site/resultTab. [23 Oktober 2016].

Combrink, N.J.J. 2013. Calcium-related plant physiological disorders. Acta Hort. 1014(2): 7-12

Danner, M.A., S. Scariotto, I. Citadin, G.A Penso, L.C. Cassol. 2015. Calcium sources applied to soil can replace leaf application in 'Fuji' apple tree. Agropec. Trop. 45(3): 266-27.

de Freitas, S.T.D., C.V.T. Amarante, J.M. Labavitch, E. J. Mitcham. 2010. Cellular approach to understand bitter pit development in apple fruit. Postharvest Biology and Technology. 57: 6-13.

de Freitas, S.T.D., M. Padda, Q. Wu, S. Park, E.J. Mitcham. 2011. Dynamic alterations in cellular and molecular components during blossom-end rot development in tomatoes expressing
sCAX1, a constitutively active $\mathrm{Ca}^{2+} / \mathrm{H}^{+}$ antiporter from Arabidopsis. Plant Physiology. 156: 844-855.

Dorly, S. Tjitrosemito, R. Poerwanto, Juliarni. 2008. Secretory duct structure and phytochemistry coumpounds of yellow sap in mangosteen fruit. Hayati J. Biosci. 15: 99-104.

Hocking, B., S.D. Tyerman, R.A. Burton, M. Gilliham. 2016. Fruit calcium: transport and physiology. Front. Plant Sci. 7:569.

Jemric, T., I. Fruk, M. Fruk, S. Radman, L. Sinkovic, G. Fruk. 2016. Bitter pit in apples: pre- and postharvest factors: A review. Spanish Journal of Agricultural Research. 14(4): 1-12

Greenberg, J., I. Kaplan, M. Fainzack, Y. Egozi, B. Giladi. 2006. Effects of auxins sprays on yield, fruit size, fruit splitting and the incidence of creasing of 'Nova' mandarin. Proceedings of X International Symposium on Plant Bioregulators. In Fruit Production. http://www.actahort.org/books/727/727 _28.htm. [24 Mei 2013].

Karin, L. 2013. Auxin metabolism and homeostasis during plant development. Development. 140(5): 943-950.

[Kementan] Kementerian Pertanian. 2015. Buletin Bulanan Indikator Makro Sektor Pertanian. http://pusdatin.setjen. pertanian.go.id/kategori2-46-buletinmakro.html. [18 Mei 2016]

Kramer, E.M., E.M. Ackelsberg. 2015. Auxin metabolism rates and implications for plant development. Frontiers in Plant Science. 6(150): 1-8.

Kurniadinata, O.F., S.O.S. Depari, R. Poerwanto, D. Efendi, A. Wachjar. 2016a. Solving yellow sap contamination problem in mangosteen (Garcinia mangostana) with $\mathrm{Ca}^{2+}$ application based on fruit growth stage. Communications in Biometry and Crop Science. 11(2): 105-113. 
Kurniadinata, O.F., R. Poerwanto, D. Efendi, A. Wachjar. 2016b. Mengatasi cemaran getah kuning pada buah manggis (Garcinia mangostana) dengan aplikasi kalsium dan teknologi lubang resapan biopori. J. Hort. 26(1): 59-66.

Kurniawan, V., R. Poerwanto, D. Efendi. 2016. Waktu dan dosis aplikasi kalsium dan boron untuk pengendalian getah kuning pada buah manggis (Garcinia mangostana L.) di tiga sentra produksi. J. Hort. Indonesia. 7(1): 21-30.

Marschner. 2012. Mineral Nutrition of Higher Plants. $3^{\text {th }}$ edition. Academic Press, United states.

Martias, R. Poerwanto, S. Anwar, R. Hidayat. 2012. Hubungan antara ketersediaan hara tanah dan cemaran getah kuning pada buah manggis. J. Hort. 2(22): 111118.

Osman, M., A.R. Milan. 2006. Mangosteen Garcinia mangostana L. Southampton Centre for Underutilised Crops, England UK.

Pechkeo, S., S. Sdoodee, C. Nilnond. 2007. The effects of calcium and boron sprays on the incidence of translucent flesh disorder in mangosteen (Garcinia mangostana). Nat Sci. 41(4): 621-632.

Poerwanto, R., Dorly, M. Maad. 2010. Getah kuning pada buah manggis. Hal. 255260. Prosiding Seminar Nasional Perhimpunan Hortikultura Indonesia. Reorientasi riset untuk mengoptimalkan produksi dan rantai nilai hortikultura. Bali, 25-26 Januari 2010.

Poovaradom, Sumitra. 2009. Growth and nutrient uptake into mangosteen (Garcinia mangostana L.) fruit. Proceedings of the International Plant Nutrition Colloqium XVI. Davis US. http://www.escholarship.org/uc/item/5r k9h6k2. [11 Januari 2011].

Purnama, T., R. Poerwanto, D. Efendi. 2013. Aplikasi kalsium dan boron untuk pengendalian cemaran getah kuning pada buah manggis. J. Hort. 23(4): 350-357.

Pusat Penelitian Tanah. 1982. Kriteria penilaian data analisis sifat kimia tanah. Badan Penelitian dan Pengembangan Pertanian. Departemen Pertanian.

Saure, M.C. 2005. Calcium translocation to fleshy fruit: its mechanism and endogenous control. HortScience. 105: 65- 89 .

Seligmann, R., U. Wengrowicz, D. Tirosh, U. Yermiyahu, A. B .Tal, A. Schwartz. 2009. Calcium translocation and whole plant transpiration: spatial and temporal measurements using radio-Strontium as tracer. Proceedings of the International Plant Nutrition Colloqium XVI. Davis US.https://www.researchgate.net.public ation/235616014. [18 Mei 2013].

Setyaningrum, Y.I, Dorly, Hamim. 2011. Respon morfo-fisiologi dan penurunan skor getah kuning buah manggis (Garcinia mangostana L.) terhadap aplikasi Ca secara eksternal. Hal 829837. Prosiding Seminar Nasional Perhimpunan Hortikultura Indonesia. Balitsa Lembang, 23-24 November 2011.

Syah, M.J.A., T. Purnama, D. Fatria. 2009. Teknologi pengendalian getah kuning pada buah manggis. [terhubung berkala]. http://www.pustakadeptan.go. id/inovasi/k1070102. [24 September 2015].

Taleb, R., A. Zahra, M.K. Hasan, H.S. Hasan. 2012. Effect of different auxin concentrations on Virginia Creeper (Parthenocissus quinquefolia) rooting. World Applied Sciences Journal. 16(1): 07-10.

Taiz, L., E. Zeiger. 2010. Plant Physiology. $5^{\text {th }}$ edition. Sinauer Associates Inc. Massachusetts.

Tanari, Y., D.D. Tinggogoy. 2014. Pengendalian getah kuning manggis melalui pengaturan dosis kalsium. Jurnal Agropet. 11(1): 15-23. 
J. Hort. Indonesia 9(1): 10-18. April 2018.

Thimann, K.V. 2008. Auxins and the inhibition of plant growth. Biological Review. 14(3): 314-337.
Vince, O., M. Zoltan. 2011. Plant Physiology. Digital textbook library. [13 Maret 2017]. 